\title{
ANNALS
}

OF THE

\section{AMERICAN ACADEMY}

OF

POLITICAL AND SOCIAL SCIENCE.

\section{THE PROGRESS OF ECONOMIC IDEAS IN FRANCE.}

Ever since men have lived in society the observers among them have been gathering economic notions, and some of the most elementary, such as that scarcity enhances value, have been well known since the earliest times. But it was not until the eighteenth century that an attempt was made to gather these notions into a philosophy, to construct an Economic Science. This first attempt, which resulted in the so-called Physiocratic school, was not a happy one. I shall not enumerate its errors here; others have done this. It is of more modern times that I wish to speak. We ought, however, to note that the Physiocrats merit recognition for striving to base Economic Science on the nature of things, for having seen that the relations among men are influenced by various causes and that an economic cause just as surely as a physical cause, is followed by its effect.

The English who had had occasion to correlate various economic phenomena adopted what was good in the system of the Physiocrats; Adam Smith remodeled the doctrine, 
eliminating its chief errors. Ricardo, Malthus and others added their theories, and when the young Economic Science, thus recast and improved, returned to France, J. B. Say added some complementary notions and gave it form, method and clearness. Political Economy now spread much more rapidly and made for itself a place in the scientific world and soon in the political world also.

Up to that time it had not occurred to any one to consider Economics as a stationary science, for it was obviously changing constantly. It continued to advance and develop, however, until no one longer hesitated to consider that the science was established. The fundamental principles had been found, it remained only to discover how those principles were to be applied in the various problems which might confront the State and Society.

The many writers who were the contemporaries, and especially the successors of J. B. Say, were substantially agreed as to principles, for they were followers of the same masters; but they were much less in accord in regard to practice, and these differences of view would have been sufficient to prevent stagnation in the economic world by giving rise to discussion. There were dissenters, however, to be found during the whole period. I cite only Sismondi among the economists. There were the socialists-St. Simon, Fourier, the phalansterian, Pierre Leroux, later Louis Blanc and Proudhon, and finally, last but not least, there were the protectionists. For it was with these last that the struggle was fiercest and longest, and it was, perhaps, this very struggle which seemed to create about the middle of this century a family bond among the French economists. It was the exigencies of practice which gave a great and peculiar importance to the question of free exchange, and have made more than one of the writers of the time believe that political economy was purely and simply the theory of free trade. But this was a singular belittling of its scope and dimensions. One had only to open one of the treatises or manuals of the time to see that Economic 
Science had to do with very many other questions, and that of a hundred pages, barely two were devoted to the freedom of commercial exchange.

Among the economists whose earlier writings go back to the first half of this century there may be mentioned Bastiat, Gustave de Molinari, Courcelle-Seneuil, Dunoyer, Cherbuliez, Rossi, Ad. Blanqui, Joseph Garnier, Ambroise Clement, Michel Chevalier, Wolowski, Gustave du Puynode and others, who are here omitted in order not to prolong the list. The works of these authors are sufficiently well-known to make it unnecessary to add their titles.* These economists, with J. B. Say and others, as well as almost all English, American, German and Italian economists are to-day classed as belonging to the "classical" or liberal school. It is sometimes called the "orthodox school," but I cannot accept this designation ; first, because it has nothing to do with religion in which one believes-in which one can believe the true, (orthodoxy) or believe the false, (heteradoxy) according as one is inspired more or less from on high. No ; political economy is a science; if writers have properly observed causes and effects, ONE KNOws; if they have not rightly observed, then ONE DOES NOT kNOW. I present a second objection to the word orthodox; it is that although there have always been differences of opinion among economists and although these differences have been of a certain importance, yet it is true that they did not, for that reason, consider themselves hostile to one another.

It is since the rise of the "new schools" that names more or less significant have been given to the one of which Adam Smith is considered as the founder, and the term "classical" is fairly suitable, although I prefer the term liberal, and it is that which I advocate. Some German and Italian writers, the one echoing the other, have occasionally divided the school and distinguished in its ranks an "optimistic school" in recognition of Bastiat, who wrote "Les harmonies

\footnotetext{
* The catalogue of their books may easily be obtained gratis from Guillaumin et Cie., Paris.
} 
economiques," and also because certain French writers in opposition to extreme official regulation have based their reasoning somewhat too emphatically on the propcsition that every man knows best that which is most expedient for him. But this is mere caviling. First; it goes without saying, that the economist who writes every man, has in mind only intelligent men. Second; all the schools, or to be more exact, all those who believe that they have reached the truth, are optimistic relatively to their doctrine; of this I could bring forward curious and convincing proofs. I do not then give serious consideration to the name "optimistic school," and content myself with a passing mention, which is all that the term deserves. It is then with the classical or liberal school that we have to do, and if we wish to show the progress of economic ideas in France we must, in the first place, understand what is meant by the "classical school," and what are the peculiarities that distinguish it from other schools. I am convinced that this definition has not yet been given, unless perhaps vaguely, and by the opponents of the school. Science demands clearness and precision; it must know how to distinguish that which is essential from that which is accidental, that which is general or objective from that which is individual or subjective. This, then, is the definition : The "classical school" bases economic science on the study of man living in society, striving to satisfy his material and immaterial wants. Political economy is therefore a science of observation. Naturally it studies the man of to-day. One can observe only what one can see; but the records of history which we possess show us the same man; he has not changed since the earliest times, and until the contrary is proven, we may reason on the basis that human nature will always be as it has always been.* So it is with the laws which govern the visible world, the solar system, the mineral, vegetable and animal kingdoms, physics and

\footnotetext{
* I refer to human nature and not to its manners and customs, nor to the organization of States and governments. Thus, every mann provides food for himself; it is nature's law : what he eats and how he eats depends on the manners and customs of the time.
} 
chemistry. We can and should consider these laws as eternal.

These two premises are sufficient to authorize us to declare the permanence of great economic laws, since these laws have to do with the means which man employs to draw from nature that which is necessary for the satisfaction of his wants ; for nature does not, of herself, place these necessities at his disposition. If men could live on the spontaneous products of nature, there would be no political economy.

The material wants, the rational satisfaction of which maintains man in life and health, consist principally in food, clothing and lodging. The immaterial wants are varied; they are more numerous in the case of the civilized man than in that of the savage. It is a want, at once material and immaterial to avoid pain and to seek pleasure. The ensemble of these different wants constitutes human nature, and it is from their reactions, the one upon the other, that economic laws proceed.

The first of these laws is this: man tends to obtain the greatest possible result with the least effort. Effort, work, is more or less laborious for it is necessary to overcome the force of inertia which is natural to all bodies whatsoever. This law is eternal. It applies to the ape which is called man's ancestor and to the oyster, which is believed to be the progenitor of the ape.

The second law is, that man will make no effort to obtain that which will give him no material or moral satisfaction, that which is useless or disagreeable, or which he cannot exchange for some useful object or for a service rendered. It is by deduction from this law which in its development becomes the law of "final degree of utility" of Jevons or the "marginal utility" of Carl Menger,* that one is able to explain why what is rare is dear, and why that which is abundant is cheap. Is not this also, an eternal law?

\footnotetext{
* "Grenznutzen," a term which I have rendered in French by " la moindre jouissance," in my work "Le Proges de la science economique." Paris, Guillaumin et Cie.
} 
The third is that all production is facilitated by means of appropriate instruments; and in almost all cases is possible only by the aid of these instruments. You wish to fell a tree: you must have an axe. You wish to weave a piece of cloth : you must have a thread and a loom. You wish to cross the sea : you must have a boat. Instruments, raw materials, provisions and all means useful in production have been grouped under the name of capital. This law that capital facilitates production or renders it possible, is eternal.*

In a society where men hire themselves out as laborers, the great majority, perhaps all-as daily experience teaches us-prefer a remuneration which shall be fixed, regular, certain, even though it be moderate, to one which is larger, perhaps much larger, yet contingent.

This, then, is a result of experience, which confirms what we know of human nature, i. e. (I) Man, having a body, in order to work must struggle against the inertia inherent in all bodies. (2) It is the intellectual and moral power, the soul, with which man is endowed which obliges the body to work ; but who will incite the intelligence which is so often sluggish? Now the study of human nature teaches us that a fixed salary favors repose of mind ; a contingent return makes it uneasy ; uncertainty is trouble and man flees from trouble.

For man then, as we observe him, a fixed salary will be almost always the form of remuneration preferred. If there are exceptions they seem to prove the rule.

There are other eternal laws, but this is not the time to inquire regarding them, for we are not making an exposition of the science, we are defining it simply.

* The attempt has been made to make of capital a "category of history," a transient thing, since although there are cases where he who works possesses also capital; here are others where one furnishes the capital and the other the work, and the two individuals must be associated to secure the product. But this objection is pure sophistry. Capital remains capital whoever posesses it. It is especially Karl Marx who has distorted the meaning of the word, and has tried to give it another signification than that which science has recognized. According to Karl Marx, the hammer, the plow, the machine, etc, are instruments if the owner himself makes use of them : they become capital only when the owner places them in the hands of his workmen. 
Some one will ask, does the classical school also admit historic laws, i. e., temporary laws? Undoubtedly. Production by means of slaves has its laws, but these laws operate only during the existence of slavery. It may also be said that the law-the relation of cause and effect-is eternal, yet it is in operation only so long as there are slaves. It is the same with machines, with the telegraph and with all things which can have an economic influence.

One must not confound the law with the forms which it may assume or the applications which may be made. Societies are modified, they take on different aspects; but the question is always of men living in a society, with the relations which result therefrom; and the nature of these men has not changed, so long as we have known them, i.e., in the years covered by history.

Should we infer from the fact that the classical school admits economic laws which are eternal, that it is opposed to progress? That would be a gross error. In the first place, it does not claim that these laws are good; it simply says, it is thus that the nature of man is presented to our intelligence, since there have been men and wherever there have been men. That which is not general and eternal is not a law. In natural laws we are not able to effect a change. Gravity, attraction, affinity, the need which living creatures have of food, etc., are facts which man must accept as the basis of his reasoning and of his actions. But for all that remains-and what remains is immense, infinite- the play of human thought and act, of tendencies, of aspirations, of effort, is free, and this play is so much the more active in proportion, as man has climbed the ladder of progress. In fact, climbing the ladder of progress means gaining a better knowledge of natural laws and the power to make greater use of them. Economists have always been very earnest for progress, and he who makes a contrary statement calumniates them.

A recent author seems to reproach the classical school for not having often made use of the term so much in fashion, 
"Evolution." This author seems to be ignorant of the fact that "Evolution" is not a synonym of progress; Evolution comprehends childhood, youth, manhood, but it embraces also old age and decrepitude, which leads to death.

The word individualism is sometimes used to designate the doctrines of the classical school. If by that it is meant that the liberal economists are not socialists, then the expression is only a simple truism. If it is meant that the economists hold that society exists in the interest of the individuals which compose it, that is the expression of a truth which every one feels and acknowledges, and which does not prevent one from sacrificing himself for the general good. It has happened that lots have been drawn to determine who should devote himself to the general interest. Can we conceive of a society that is not composed of individuals? Socialistic society itself has no other aim than to procure more enjoyment for every one of the individuals who ranks himself under its banner.*

Economists opposed to the intervention of the State have also been called individualists. Some have pretended to believe that economists reject absolutely the intervention of the State, and it is in this manner that the famous motto of Gournay has been interpreted "laissez faire, laissez passer." But this is an exaggeration. The economist admits the intervention of the State whenever it is proper, and he has never recommended absolute "laissez faire." The word "absolute" is a textual falsification. Events have unfortunately rendered the debates between this school and others heated, and in a passion one always goes too far. The aggressors so far forget themselves sometimes as to employ arms which are little creditable.

Finally, competition is likewise a characteristic of the classical or liberal school ; however, outside of the communists, all the schools are brought to respect competition more

* The opposition between the propositions: (1) Society is the whole, individuals are the parts of it; and (2) The individual is the fundamental element, a group of men forms the aggregate called society; a metaphysic subtlety: and the first proposition finds no practical application when the masses take part in legislation. 
or less; it is impossible to avoid it. In reality, the new schools are distinguished only by the greater or less repugnance which they exhibit in submitting to this necessity. They avenge themselves by insults. The classical school has, for a long time, committed the error of not separating with sufficient clearness, pure science from its applications. If it had done this it would have suffered fewer attacks, for all schools admit the dicta of pure science, for they are forced to do so. $\hat{E}$. de Laveleye has said that scarcity creates dearness, abundance brings cheapness. Every housekeeper knows this. Is truth less true because it is conumon? Every child knows as well as the most illustrious mathematician that two and two make four. What the housekeeper and the children do not know are the applications and deductions to which these elementary truths lend themselves.

Theory interests only a small number of studious men; practice, that is to say, the applications interest every one. The effects of these applications extend further than one would suppose. In the first half of this century political economy, as it was taught in the books of J. B. Say, Bastiat, Molinari and others had to encounter but two kinds of adversaries-the socialists and the protectionists. But both were concerned more especially with the applications, with what the Germans call economic policy, and more recently, social policy, (Wirthschaftspolitik und socialpolitik).

Socialism dates far back in France, especially if we take account of the authors of Utopias. The St. Simonists were the first who attracted public attention, but without exercising any influence over the masses. The St. Simonists' doctrine seduced only certain youths of the upper class, for it was aristocratic; it proclaimed, "to each according to his capacity." It was too fine! Vertigo supervened ; the chiefs of the school fell into fantasticalness and the meteor vanished; but not without some noise. Some of the adepts, followers of the school of St. Simon, Michel Chevalier, the brothers Pereire, became good economists in maturer life. 
Pierre Leroux,* a mystic, who first employed the word socialism, did not create a school. Buchez, the author of a "Treatise on Politics," and of a collection of documents upon the Revolution of 1789 , originated, after or about the same time as others, co-operation, which was then called partnership $\dagger$ (association). His influence did not last. Fourier, the phalansterian, founded a school. His principle was very attractive. He wished to have labor become a pleasure and delight. Such a doctrine might have captivated the masses, but the masses had little knowledge of the works of Charles Fourier, for he wrote in a style intelligible only to cultivated men, who were willing to take the trouble to understand him. He had but few disciples, and among them Muiron, Considérant, Cantagrel, Pompéry, Pellarin, Bureau Tousserel, Bovier and some others made themselves known through their writings. Few partisans remain of this Utopian doctrine, which aimed at the happiness of the human race, an end, alas! very difficult to attain.

The first socialist who reached the masses was Louis Blanc. The first edition of his "Organization of Labor" (Organization du travail,) which has been reprinted nine times, bears the date, 1839 : he also developed his ideas in many other publications; for example "Le Socialisme, Droi au travail," (The Right of Labor) third edition, Paris, 1849, and "Le catéchisme des Socialistes," (The Socialists' Catechism ") Paris, 1850. He proposes a sort of communism with notions borrowed from St. Simon, Fourier and Owen. He sets forth the rights of labor and recommends the erection of national workshops. What has made his doctrine acceptable to so many men is, that he says, not "to each according to his works, " but "to each according to his needs." I knew Louis Blanc well, and have always found him a false reasoner. He should have known that it is morally

\footnotetext{
* His principal work is "De l'humanite, de son principe el de son avenir," 2 vols.; Paris, 1839 . Second edition, 1845 . "Socialism" is discussed by him in the Revue Sociale (1845).

† Sometimes a distinction has been drawn between partnership (associalion) and co-cperation, but it has never been generally understood.
} 
and physically impossible to procure for all men the satisfaction of all their "wants." There are so many fictitious "needs," and these multiply with the real or imaginary ease in satisfying them. This from the moral point of view, as to the physical possibility, one might, perhaps, promise dry bread to all men, especially in abundant years; but one could not give every one meat and wine. There would not be enough of these commodities upon the earth for each one to have his share. And how many other desirable things are still more scarce!

About the same time Proudhon appeared, a man with great talent as a writer and one who loved to astonish the reader with the grandeur of his paradoxes. Every one knows his famous pamphlet, " Property is Theft." (La Propriété. c'est le vol!) He had a celebrated discussion with Bastiat upon interest as gratuity which did not reflect great glory upon him. With such an idea he could not gain very serious adherents, because those who possess and those who do not possess capital know equally well that property cannot be lent gratuitously (except through kindness to a friend) and the idea of creating money by means of a printing press could not take root in France, where so many families had been ruined by the assignats of the Revolution. The idea of exchanges in kind by means of certificates of labor (instead of money) was too retrograde to charm*. Proudhon also wrote "Economic Contradictions" (Contradictions économiques) but this work was not intended for the people. The author amuses himself in playing with hegelianism, thesis, antithesis, synthesis. It was not very interesting to the masses, but was, perhaps, suggestive to a small number. The book aroused discussion, but $I$ do not believe that it contributed to the advancement of the science. One of his other books (they are so numerous that they cannot all be mentioned here) "Anarchism," helped, with the aid of Krapotkine's

* It is possible that it was from Proudhon that the socialists derived the idea of paying labor in paper certificates. 
work, to bring into existence the anarchist class; and that will not add laurels to the memory of Proudhon.

In a word, the socialistic schools of French origin have exercised no sensible influence upon economic doctrines, nor have the advocates of protection. Moreover, the protectionists gave no attention to theory ; they sought to prove the necessity of import duties by insisting on the superiority of English goods or on the need of preserving the home market. Thiers said: "Great energy is expended in discovering arguments for the system of protection, but there is but one, and that is very simple: it is the preserving of the home market." Among the writers in France who, previous to 1870 , wrote in favor of protection, may be mentioned Lestiboudois, Fanconnier, Burat, de Mesnil-Marigny, $\mathbf{H}$. Richelot (the translator of List), Hervé-Bazin, and even the former Duke de Broglie. But since it was a matter of practical questions, it was rather in parliamentary discussion and in the newspapers that the opponents of free trade expressed their views.

An exposition of these ideas is to be found in the wellknown works of the late M. Amé, former Director-General of Customs, upon the history of import duties in France (Paris, Guillaumin, I877). We learn there that it is usually interested parties who defend their particular industries Sometimes, too, they have taken occasion to attack the doctrines of the economists, but so vaguely that these attacks could be scorned. Take, for example, a passage from Amé ("Etude sur les tarifs des douanes," vol. ii. page 225, chap. xxi.). During an interpellation of the ministry in 1868 , after the treaty with England, a deputy, M. Kolb-Bernard, attacked political economy in these words: "Humanity wishes enjoyment. . . . There was formerly in the moral world a principle of sacrifice, from which rules of sobriety and moderation in the general practice of life, were derived.

The spirit of sacrifice has been repudiated as an insult to the law of progress. For necessities, which have their moral limit, enjoyments have substituted, which have 
none. The necessary has advanced even to the superfluous. Luxury has been proclaimed a social force. Its morality has been made to depend on its utility. It is no longer duty, it is enjoyment, it is cupidity which have become the motif of labor. This is the basis upon which modern economic science rests."

But is not all this empty and irrelevant rhetoric? And these fine phrases upon the cupidity of others (who nevertheless, asked for nothing), are they not intended solely to justify their own greediness ; for customs-duties demanded by the protectionists had no other aim than to enable them to sell their commodities for a higher price, that they might enjoy the luxuries that riches give, and this at the expense of their fellow-citizens. It is obvious that this selfish polemic can not influence the views of economists. It leads to no new economic law, to no relation of causality, to no moral principle, to no new application. Besides, it does not reach the foundation of things, and, when the circumstances were favorable, customs-taxes were raised without taking the trouble to construct a theory. Far from it. More than one militant protectionist has said, "I am, in reality, a freetrader; but at present the general interest calls for protection."

In the third quarter of this century a current of thought was set in motion, very feeble it is true, and not reaching the masses; but one which ought to be mentioned here; I speak of the Le Play school. I knew its founder and I was not in sympathy with him; but he gathered around him zealous disciples, drawn toward him, doubtless, by the Catholic religion as much as by his economic doctrines. He did not really occupy himself with pure science, being, indeed, rather a moralist than an economist. Even in this capacity, in the opinion of good thinkers, he was frequentiy wrong. To establish a family, he wished to give to the father the right to create an heir, "faire un aine" by devising his fortune to one of his children, imagining that this would point a moral to the others. In France, owing to remembrances 
of the ancien régime, as well as an ingrounded sentiment of equality-and, let me add, through love of justice-we prefer that generally, ${ }^{*}$ the father should treat his children alike. But this point has not really the importance which In Play attributed to it. Innumerable cases since Cain and Abel could show as much evil as good resulting therefrom. Although Le Play was much in sympathy with the Middle Ages, he did not advocate the corporations of arts and trades (guilds); he preferred freedom of labor (as do the economists); but he recommended patronage, that is to say, the establishment by the employer of institutions useful to workmen. Unfortunately, these institutions do not yield the good that Le Play expected from them. He hoped to gain something also from co-operation, but not much. One of his disciples thus expresses the view of the master upon this point. "The obstacle which will always oppose itself to the unlimited development of co-operative societies for production is, that they do not suit the masses; lacking as these do the moral qualities required by all collective action; nor do they suit energetic natures who feel themselves capable of standing alone. They favor exclusively that restricted class of workmen, who, by their good conduct, adapt themselves readily to the exigencies of co-operative labor, without possessing the initiative indispensable to success under the régime of liberty."

Le Play has given much attention to monographs upon the family and the workshop. He first published "Ouvriers européens," afterward "Ouvriers des deux Mondes." These monographs- $a b$ uno disces omnes-claimed to present the people by means of what were considered, sometimes erroneously, as types. But this claim does not seem to me well founded. I have discussed this point with Le Play, preferring to rest upon numbers rather than upon units, and the learned engineer could not refrain from partially indorsing my views by admitting that both methods were equally

\footnotetext{
* The Civil Code (Art. 9r3) gives the father a certain latitude by which he may grant advantages to one of his children.
} 
good ; but he nevertheless limited himself to writing or promoting the preparation of monographs, without resorting to statistics.

The Society of Social Reform which Le Play founded in $185^{6}$ continues to follow the same defective plan. One of his disciples, now the president of this society, M. L: Cheysson, has recently published in collaboration with $M$. Alf. Toqué a work entitled "Les Budgets comparés ou cent Monographies de Famille" (Comparative Budgets or a Hundred Family Monographs). Now, let us refer to page ro8 et seq., which relate to the workmen of Paris, and make comparisons. We will take (page I Io) but two types, the tailor and the weaver of shawls. No two amounts bear any analogy. We shall find that the tailor spends 667 francs 50 centimes for food, besides his housekeeping expenses (20 per cent of the outlay) : the corresponding expense of the weaver is but $67 \mathrm{fr}$. 70 (3. I per cent). The stone-cutter, the longshoreman and others spend nothing outside the house expenses. Can the tailor, the subject of the monograph, be called a type? Do the majority of tailors have heavy expenses outside of the household expenditures? That would be a mistake. And where can one find the type of the workmen of Paris? Until there is a new order of things, I do not believe that the "Monographs" contribute or will contribute to the solution of the social question.

The movement of economic ideas in neighboring countries exercised a very imperceptible influence upon France before I870; for the doctrines which obtained here prevailed also in all other civilized lands, There certainly were dissidents and the United States even furnished one whose merit was generally recognized in Europe, and who had disciples there. I speak of Carey. I appreciated Carey and helped to make him known; but I did not accept any of his ideas, though we have often discussed them together. But he has been a leaven. Agitators too have not been lacking among us. Paris, since 1842 , has had a Society of Political Economy ; it was certainly founded by prominent members of the classical 
school, but it has never rejected any one because of his opinions, not even protectionists, although they are in a minority. I know a Fourierist there and dissenters of different degrees. This diversity of views renders that " clashing of opinions" common which, according to the proverb, "strikes the light." Then to the monthly meetings where there are discussions after dinner, foreign economists are welcomed. They have always sought distinguished strangers, who have no trouble in gaining admission; and they are listened to with pleasure if they have anything to say. There has never been stagnation of ideas among them, but the progress realized has not made any great impression, less because it was feeble than because it did not reach the root of things. Fundamental principles have maintained themselves, but applications have been developed. So that many times profit-sharing, co-operation and other questions have been the order of the day.* Lassalle, who died in I864, and Karl Marx, who died in 1883 , produced an agitation which was felt even in the economic world that had the least sympathy with agitators who held views which were rather political than economical.

The International, founded by Karl Marx long before 1870 , created in the sixties a certain socialistic movement in France, at that time well restrained it is true by the government; but a movement which did not influence the economists, because there was too great a difference in doctrines of the two. In order that socialists could act upon French thought, their ideas must undergo a metamorphosis which approximated them to economic doctrines ; or, more exactly, it was necessary to remove as far as possible that which was too revolutionary and repulsive. This metamorphosis took place in Germany. I venture to tell in a few words how it has been accomplished, for I have watched it from the beginning and followed it, so to speak, from day to day. At the time

* From time to time the discussions of the Sociktk d'economie politique de Paris have been published in the Journal des Economistes (Guillaumin); later in l'Economisie Frangais. They are now published separately. The collection can be obtained complete. 
when Lassalle began his career as a popular orator a certain number of German professors of political economy, who to-day shine in all their glory, were young men. Young men, especially if they are cultivated, are often generous minded, or allow themselves to be captivated by generous ideas ; but as they lack experience, they also are easily attracted by appearances and fail to take account of possibilities. These young professors, attracted by the glowing phrases of the ambitious agitator Lassalle, $*$ and inspired also by the works of Karl Marx and other reformers, set themselves to teaching doctrines highly flavored with socialistic propositions. Some attacked with violence the principle of private property ; almost all expressed themselves in favor of the workman, and with an avowed partiality. It is this which brought to them the surname of cathedra-socialists. $\dagger$ These professors by participating in the polemics of the day abandoned the freld of science; they found themselves restricted there. Science is primarily occupied in studying the relations of cause and effect, laws and general principles; and if, by reason of these studies it finds that certain effects cause suffering, it contents itself by giving a passing counsel to those who suffer, considering that it is to art, to practice and not to science that action and especially benevolence appertain. The partisans of science have had, perhaps, too much confidence in human nature and taught that it was essential to human dignity that everyone should extricate himself from embarrassment by his own efforts.

There was next formed in Germany a new school, which called itself sometimes historical, sometimes ethical, but might more justly be called the paternal school. $\ddagger$ It made an active attack on the classical school, which was composed

\footnotetext{
* To Lothar Bucher is attributed the assertion that in 1864 Lassalle began to see the hopelessness of his efforts and was on the point of abandoning them.

+ Kathedersocialist, a word invented by Oppenheim. They, on their side, invented the word Manchesterschule, which was silly enough, for neither Cobden nor Bright had advanced anything new.
}

$\ddagger$ For two reasons : (1) Because it does not recognize liberty as a rigbt; (2) Because it exaggerates the mission of the State. 
of the more or less faithful disciples of Adam Smith, Ricardo and J. B. Say. The chief reproach brought by the new school at the first meeting of its partisans at Eisenach, in 1872 , was that the older school spent itself in sterile theories and did not attempt to ameliorate the condition of the lower classes.* The new school desired to devote itself chiefly to social reform. This aim was very well in itself, and the theoretical school might have been usefully supplemented by a practical school ; they might, perhaps, have shared the work amicably, division of labor being a means of progress. But the young reformers became too aggressive and thought it their duty to attack theory itself in order to justify certain peculiar views. Then stormy controversies occurred, but since then the reformers have learned that their profession had its difficulties, and that the economists, their predecessors, have not always been wrong. The views of the two schools have thus, to a certain extent, approached each other. Be that as it may, as these young professors did not accept the whole of the socialistic opinions put in circulation by Lassalle, Karl Marx and others, as they spoke with talent and with a certain moderation, as they held the high and honored position of professors in the university, they became the bridge by which socialism could pass into the scientific world of many neighboring nations. And who knows whether the recent victories of the German armies may not have been of some influence? One particular, fortuitous circumstance contributed more than might have been expected to spread the doctrines of the new school. This was not the love of something new, not the spirit of imitation-two great forces in this world; it was the friendship of Lothar Bucher for Lassalle. Bucher had at one time a great influence over the most powerful man of the period, Chancellor Bismarck. He presented Lassalle to him, and he certainly aroused a certain interest in the mind of the German Chancellor. This interest evoked the idea that there was, perhaps, a grain of truth

\footnotetext{
* This reproach, as can easily be shown, was not entirely deserved. Many attempts have on the contrary been made by it.
} 
in socialism; if it were given a little indulgence there would be all the more reason to strike it sharply, if, after having received this indulgence, it lifted its head too high. This indulgence took the form of insurance against sickness, insurance against accidents, insurance in case of infirmity and of old age, and in other laws of less importance. I shall not consider here what there is of good or of bad in these innovations, which have helped to spread the expression and the idea of "State socialism ; " that is not my task-I wish only to exhibit the facts, the events which had an influence upon the movement of ideas in Europe and particularly in France. Those grandiose creations, (which aided in propagating the democratic socialism they were intended to combat), contributed to make known and to give importance to that cathedra-socialism which appears to be identified with State socialism : or, if you please, the one became the theory, the other the practice. France was an attentive observer of this movement and none of its manifestations escaped her.* Economists who may be considered as belonging to the classical school were moved by it, but, on examination found that the German school-or schools-scarcely touched pure science. These, indeed, commence by saying that there were no economic laws, or that these were merely a farce, but for some time they have ceased to deny them, and admit that they are founded in human nature. Hence, French economists saw no reason for sensibly modifying their theories, and especially since there were among themselves notable differences of opinion which, however, did not prevent them from continuing to class themselves together as disciples of the classical or liberal school. They accepted the ameliorations of detail brought from Germany or Austria without hair-splitting or opposition. But it was not toward pure science, I repeat, that the German economists, called "Socialpolitiker," specially turned their attention;

*Without speaking of those writings which treat incidentally of the movement of foreign thought, $I$ have for forty years published every three months in the Journal des Economistes a review of the principal foreign economic publications. I have besides devoted special and extended articles to the new German school. 
but, as the word Politiker shows, toward the side of practice, French economists (and a minority of German economists have remained true to this view) have reclaimed a large field, the largest possible scope for the free initiative of the individual, and they leave to the State only its natural attributes, matters of general interest, security, and such things as are beyond the reach of the individual.

The German "Socialpolitik" school, moreover, attributes to the State a particular mission, that of regulating in detail the relations between citizens, and notably, of putting itself on the side of the weak against the strong, the feeble being the workman, the strong, the employer; and this principle, which has a certain degree of legitimacy, they exaggerated to the utmost. I must add that if, frequently, the workman is weaker economically than the employer, it is only when he stands alone. When workmen are organized, and they are organized almost everywhere now, they are at least as strong as employers, sometimes stronger.* We may even say that before the law the workmen are always stronger. I do not speak of the violence they may exercise; they are stronger, because in many cases the law can do nothing with them, precisely because they are not rich. To cite a single example: If the law prescribes under penalty that eight days' (or more) notice shall be given, in advance of the breaking of a labor contract, and the employer suddenly dismiss the workman, he will be forced to pay the fine or indemnity; if the workman break the contract without notice, he will pay no penalty. Here, then, the workman is the stronger, because justice has no hold on him.

Now the French economists do not admit that we ought to recognize any inequality before the law. $\dagger$ Weakness

\footnotetext{
*It is not to be forgotten that, if during a strike, the strikers by violence prevent other men from working, laissez faire on the part of the government is contrary to its duty.

† That does not prevent certain decrees from granting privileges to workmen. The Municipality of Paris does not allow itself to be troubled by this principle; but that is not a question of scientific theory; one favors the workman that one may be re-elected counsellor with a salary of 6000 francs-and for other advantages.
} 
must be met by benevolence. The laws should accord special protection only as a police precaution or as a measure of humanity, and not as an element in economic organization. In the economic world, it is sometimes one, sometimes another, which is strongest; a good or a bad harvest, for example, may cause a change of sides; and who can say that this movement is not essential to the social well-being.* The waves rise and fall alternately; untroubled water easily becomes stagnant. If the State intervenes, politicians interfere; there will be a hot-bed of injustice; force will overcome right. If the law favor the workman, if it accord to him superior power, matter will seek to rule over mind; there will be decadence-with or without a dictator.

The classical school in France then has not been conquered by these new ideas; it has accepted successively, certain views; it has been among the first to make experiments in co-operation ; it has sustained the mutual aid societies, pension funds, saving banks; it has recommended the assistance of workmen by employers ; it has even insisted in more than one instance on the duties of the rich, and all this without making any advance toward State socialism. It has continued to hold the standard of freedom high and firm, without being turned from its course by circumstances which seemed unfavorable. Among these unfavorable circumstances I will cite only one. France has an insufficient number of men who choose a career of political economy. France has a great number of Chambers of Commerce, and each Chamber needs a well-informed secretary, and above all one who is well grounded in economics. Half the work rests upon the secretary. A small number of these men seem well chosen, but scarcely one of them publishes anything, yet they should be especially well situated to study industrial and commercial questions. Among the secretaries of the German Chambers of Commerce are many writers; the celebrated Soetbeer, who has recently died, was formerly secretary of

\footnotetext{
* Accident, bealth and sickness, talent and the lack of it, etc., etc, are felt everywhere in life.
} 
the Chamber of Commerce of Hamburg; and among the secretaries of to-day we find young scholars bearing names made illustrious by their fathers; for example, Roscher, Soetbeer, Emminghaus and others. There are also the economic collaborators of newspapers, certain officials, certain politicians who give time to economic study, though not so much as could be wished. Some are specialists, and give attention only to details.

Some one will ask : And the professors? The teaching of political economy has been backward for a long time in France. Those in power, who were generally protectionists, have not been very amiable toward economists who believed in free exchange and defended free trade with ardor. There was first only the Chair of J. B. Say in the Collège de France, a Chair which was held successively by Rossi, Michel Chevalier and Paul Leroy-Beaulieu, the present incumbent. By degrees a second Chair has been established in the Collège de France for M. Levasseur. There are others at the School of Roads and Bridges and the School of Mines, at the Conservatory of Arts and Trades and at commercial schools. These Chairs render service, but they are too few. Let me add that there are two kinds of good professors (I do not speak of those who are not good): one content themselves with teaching well, and to do this consider it sufficient to keep well informed in science, and to prepare their lectures properly; the other endeavor to advance and make progress, to extend their influence and to write. When the number of professors is small, the number of those who contribute to the advancement of science will be exceedingly small and progress will suffer. Is not result always proportioned to means?

This reason and the desire to render political economy more accessible to men who might seek advanced instruction, led the Society of Political Economy of Paris to petition the government to establish Chairs of Political Economy in the universities. The result was, that beginning with 1876 , professorships of political economy in thirteen Faculties of Law 
which exist in France, were successively established, and the students in law were obliged to pursue the course.*

Here then is one point gained, and a very important point; but there is another not less important : where to find professors. We could not do as they do in America. I have had the opportunity to see a certain number of young American scholars who have devoted themselves to economic teaching; they came to Europe, took courses in Germany, France and elsewhere; and when they returned to their country they knew the chief languages of Europe, they were well informed upon the economic literature of the several countries; had seen many things with their own eyes and were suitably prepared for their duties. And if some of these young scholars caught a little of German Kathedersocialism, they are working to rid themselves of it and to follow a way of their own with characteristic American originality. It is different in France. To be a professor in a Faculty of Law one must first be a Doctor of Law, then an agrégé. To become an agrégé, one must take a long and difficult examination with a preparation of two or three years after having received the doctorate : it is, moreover, a competitive examination; and it has happened that from twenty candidates only three, four or five would be elected. These, are then, well versed in law, but they may not know a word of political economy. At first it happened that the dean would ask of the agrégés which of them wished to give the course of political economy, already obligatory. Some one must sacrifice himself to it. This improvised professor would surround himself with a few books, prepare for each lesson, and thus the law would be satisfied, but not science. Since then some chairs have been filled by men who have devoted themselves to political economy and who will not exchange from year to year their course in economics for one in Roman or in criminal law. If the professors remain faithful to economic science

* [Compare a paper on "Instruction in French Oniversities with special reference to Instruction in Public Law and Economics in the Law Faculties," by Leo.S. Rowe, published in the ANNals, Jan., 1892, vol. I1., pp. 494-517; also issued as No. 47 of the Publications of the Academy.-EDITORS.] 
they can teach it ; but previous to the day when they assume their duties for the first time, their studies have in no way prepared them for their work; for in order to succeed at the competitive examinations (concours de l'agrégation) one must devote himself entirely to the study of the law, which does not suffice to make one proficient in political science. Among the professors of the Faculties there was only M. Alfred Jourdan, professor and dean of the Faculty of Aix, who had mastered the political economy that he taught; for he had added to his French studies two fruitful years at German universities. He made good use of his time, and knew German exceedingly well. He had in his library the best English, German and Italian works, and had selected them with judgment.* He died comparatively young, which was a great loss to economic instruction in France.

Among other professors of the Faculties chosen since 1876 I mention first, M. P. Cauwès, who seems to know a little German; he has published a large treatise on political economy entitled "Précis du Cours d'économie politique, etc," + in which there are many excellent pages ; but there are also those which are subject to criticism, even if we overlook the question of free trade, his tendency being toward protection. He is to be lauded for having endeavored to follow his own way, even if that way is not always good; and every one must regret that $M$. Cauwès has abandoned political economy for a Chair of the History of Law.

Among the active professors, the one who attracts the most attention at this moment is $\mathrm{M}$. Ch. Gide, of the Faculty of Law at Montpellier. He is a man of talent; but does not seem to know German, at least nothing indicates that he does ; and if I dwell upon this point-the knowledge of German-it is because M. Gide speaks like a Kathedersocialist ; and yet one cannot know their doctrines well, if he does not know the language, and the more so, because the doctrines

\footnotetext{
* He has published among other works "Cours analytique d'economie politique," Paris : A. Rousseau, 1882 .

† First edition, r881, 2 vols, Paris: l,arose et Forcel.
} 
are constantly being modified. M. Gide attacks the classical school with veritable fury, which makes him popular in Germany ; but he puts nothing in its stead. A very clear thinker Las said, "We do well to destroy only that which we can replace;" now M. Gide has replaced nothing at all. If you read his book "Principes d'économie politique," you find that he is skeptical ; he will hardly admit that a single thing is true. However, it is just to add that the distinguished professor, being of an enlightened and liberal mind, after having repeatedly oscillated back and forth, ends very often by designating as truth, the very point which the classical school always declared to be a proven principle of economic science. One or two examples will suffice to support what we have just said. In his "Principes" (2nd edition, p. 29) he says, speaking of the German school: "Neither can we share the skepticism which this school professes in regard to natural laws. Without doubt, economic phenomena vary in different countries and in different periods, but if one is to renounce the discovery, under their changing manifestations, of permanent relations, and general laws, the idea of making political economy a science must be definitely abandoned. However dangerous to science presumpiuous hypotheses may be, they are infinitely less dangerous than this confession of powerlessness." (The italics are mine.) There is no liberal economist who would not endorse this sentiment.

We can say almost as much of that which follows (p. 30 ). " In regard to that which touches the delicate question of the intervention of the State, we are in accord with the new, or German school, in recognizing in the continual development of the powers of the State an historic fact, and perhaps exactly one of those natural laws whose existence this school contests ; we agree also with the German school, that the State has the right and the duty, inasmuch as it represents the collective interest, to limit individual rights and to intervene with authority in social relations. It must be confessed, however, that even to this day, the lamentable incapacity which the State has shown, even in the most civilized countries, 
whenever it has dealt with economic questions, seems indeed, to justify the school of laissez faire; and unfortunately it seems to me that this incapacity gives no evidence of lessening; but quite the opposite. . ."*

I have given some examples of these oscillations; the book is full of them. One thinks involuntarily of the hostile prophet (Balaam) who went out to curse and each time was obliged to bless. Other young professors seek to imitate these proceedings, by means of which they can attack their predecessors, retracing their steps, however, before it is too late, to do homage to the truth. It also gives a favorable opportunity for the frequent use of the word "evolution," now so much in vogue, a term which is used without a very exact comprehension of its significance. But these innovations are not favorable to an increase in the number of economists ; professors in the Faculty of Law will not contribute by their manuals and treatises oscillating between two modes of observation-with their ifs and their buts-to multiply students. Students are questioned upon political economy in their examinations and they will look in the books of their masters for the answers which they should give. But there, frequently, the solution is wanting. They read : it is white; but it is perhaps black, too. They will often say to themselves, what a singular science! learning by heart a few answers and thinking no more about them.

It is not thus that youth should be dealt with; we owe it positive, assured results. The professor should be content to say : that is what is known. Almost all students will be content with that; all educated men ought to have some notions of the principal branches of knowledge- "des clartés de tout" says a French philosopher. These notions they receive in their youth; they remain in their memory, and that for life. They have learned little, but still something; it is enough that it should teach them to comprehend events. Some continue their economic researches, study

* The passage which I have italicized forms one of the arguments of liberal economists against exaggerated intervention on the part of the State. 
profoundly, perhaps even advance the science. Under the régime of the modern oscillatory method, nothing remains in the memory, not even the word liberty, which the most stupid of the disciples of the liberal economists never forget.

But M. Gide knows indeed how to put his oscillations aside and to strike a blow from the shoulder without too carefully distinguishing between the true and the false. Thus he has sent a libel to an American review in which the false certainly predominates. This is especially true of the following which he says of the Institute of France: "The Institute does not desire-and we can well understand this attitude by putting ourselves in its place to commit itself to doctrines which it deems dangerous to the public order, by stamping them with its official approval and thus recommending them to the world." Without doubt, if some one should teach : Kill, steal, betray your country, the Institute would not approve the doctrines even if these were set forth in unimpeachable style; but if $M$. Gide intends to insinuate that the Institute recognizes only scientific opinions which are in conformity with the views of its members, I may say he calumniates the Institute. One of the most recent prizes conferred was in a competition upon Banks. The one who drew up the report, M. Courcelle Seneuil, who has recently died, was a supporter of the free establishment (or multiplicity) of Banks. He who received the prize, M. L. Smith, defended the unity of Banks of Emission. M. Courcelle Seneuil contented himself with giving in passing some arguments in favor of his own way of thinking. All good work is recompensed without reference to any pretended "orthodoxy ;" there is none in science. Besides the members themselves of the Institute have various shades of opinion.

M. Gide is not just to the Society of Political Economy-of which he is a member-nor to the Journal des Économistes, which is very liberal. The former editor, Joseph Garnier, was so, and M. de Molinari is now, if I am 
not mistaken. The Joumal has received, if I remember rightly, articles from $M$. Gide; it has even admitted $M$. Paul Lafargue, the son-in-law of Karl Marx; I have myself had a controversy with him, in the Journal, concerning the celebrated agitator, his father-in-law. M. Gide and his colleagues afterward founded their own review, but they had trouble in sustaining it, and called foreign economists to their aid, especially German writers. Do they really imagine that it will suffice to read from time to time a fragment of Schmoller, of Brentano, or of others of that shade of thought, in order to penetrate the spirit of men so different from themselves? Then I pity them; they will labor in vain, they and more especially their disciples.

In these observations just made, I do not depart from $\mathrm{my}$ task, which consists in presenting the movement of economic ideas in France. I regret, however, that I have been compelled to add a bit of polemic. But is it my fault if a professor of economics adopts the attitude of an assailant and proceeds with a violence that would encourage the belief that he regarded himself as the victim of some conscious deception?

Besides the thirteen professors of Faculties of the State, some of whom might be somewhat disposed to imitate the German professors, if their books were accessible to them, there are the professors of four Catholic Faculties. I have questioned the most distinguished among them, M. Claudio Jannet, * whose merit is recognized even by those who do not share his religious beliefs. He expresses himself substantially thus: Catholic economists are slow to profess a science other than that which the masters in these studies have formulated at the cost of long and conscientious labor. Natural economic laws are to them the expression of the plan by which God governs the world, while respecting the liberty of individuals. There can then be $a$ priori, no discord between

* He has published among other books: (1) "Le Socialisme d'Btat et la reffome sociale." Second edition, 189o, Paris: Plon Nourrit et Cie. (2) "Le Capital, la spécu. lation et la finance." 1892 ; published by the same firm. 
these laws and the precepts of religion, which have the same God for their author. It is for loyal, scientific observation to seek these laws. Catholic economists therefore strongly repel that empiricism which holds that there is not a natural and permanent economic order, tending continually to reproduce itself. They reject the pretensions of socialists of all denominations who think they can organize society according to the conceptions of their own imaginations. Yet they emphasize particularly the necessity of struggling against the evil which tends incessantly to seize upon society as well as upon the individual. Recognizing the action of this tendency to evil and knowing that the development of human life is not bounded by this earth, they are not astonished at the imperfections of economic order nor at social suffering; and they consider that a constant effort toward good and a continual increase in virtue and individual morality, will tend to advance economic order and to ameliorate the social state. It is above all in questions of "economic policy," * that the Catholic writers show their distinct character. Forced to give attention to the historic considerations which formerly rendered useful the guild system and the seignorial regime, they nevertheless recognize the superiority of the modern plan founded upon freedom of labor, exchange and contract; but this regime exacts, perhaps, a still greater display of moral qualities to prevent antagonism from developing among men, when each has become more conscious of his rights and of his own value. So they recommend the practice of assistance (patronage) on the part of the heads of workshops and establishments, mutual benefit societies, co-operation, professional associations; and as there will always be some who suffer, they regard with favor mutual aid societies (patrimonies corporatifs) for the assistance of small proprietors, artisans and their journeymen. They consider that charity, not imposed, but directed and animated by the Church, has always an important place in the economic order.

*Volkswirthschaftspolitik, in German. 
This is the view of a very religious man. All liberal economists agree as to the necessity of giving assistance to those who suffer ; but the majority are of the opinion that the economic domain, where one produces, or acquires by means of labor or exchange, should be separated from that of charity, where necessities are obtained, not by production or exchange, but by free gift. It is at least a question of method; and is, perhaps, a question of division of labor.

I spoke at the beginning of this article of the classical school, and we have seen that what characterizes it, is its scientific doctrines; for there can be a divergence of opinion in respect to actual practice, without necessitating withdrawal from the school. Science leaves nothing to arbitrariness, it exacts serious proofs; practice depends in a certain degree on individual calculation, and this in turn is influenced by events, by conjunctures, by environment, and why not also by the temperament of the individual, by his faculties and by the degree of his knowledge? The applied science, that is to say, the practical economics, tends frequently to react against theories. This tendency has been seen in Germany, and may now be observed in England, in France even ; in fact to some extent everywhere, but without result. Fundamental principles have not been shaken. Wherever men have attacked principles they have had to content themselves by denying them purely and simply. But that produced little effect. Thus Cliffe-Leslie once discussed in the London Athaneum the principle of the least effort ; he sought to prove that man does not try to obtain the greatest result with the least effort, but he convinced no one. Others have wished to question the influence of supply and demand, equally in vain. Has not this principle or this law a close relationship with the effects of scarcity (dearness) and of abundance (cheapness)? And these effects have very recently found their complete explanation in the final or marginal utility (Grenznutzen) of the Austrians.

In France certain statesmen and publicists have said : Let us leave science alone; it is too well established not to be 
proof against our attacks; let us ignore it. Let us act as if it did not exist, and let us advance our practical ideas. It is thus that State socialism has acted. There have been powerful arguments in favor of this course, and they are summed up in the power of universal suffrage. This power is very great, and is at once material and immaterial in its nature. It is of a material nature to the ambitious, for it is universal suffrage which procures the honors and advantages which those seek who follow a political career. It is of an immaterial nature in that it induces imitation. Imitation is a great social power; few persons resist the influence of example, above all, of a widespread example which has numbers to recommend it, if nothing else. Generally, one does not like to belong to the minority ; some, because numbers awe them, numbers seem to them to guarantee truth, wisdom, or advantage, at any rate; others, because they feel themselves too much alone in a minority; they feel almost ridiculous, and a French proverb says, "Ridicule kills." But it is the socialistic influence which dominates now among the masses; not that they know the theories of Karl Marx well; have the masses in fact ever known thoroughly the dogmas of their religion? They believe in a general way, and follow the men who have their confidence; and these men promise them a greater share of the goods of this world. This is all that nine-tenths of the voters understand. The leaders make pretense of having a doctrine-collectivismbut they know that it is, in reality, impracticable and unrealizable. Every one of them, Karl Marx and all his successors, have recoiled before a compilation of a comparative table of skilled labor (how many days of unskilled labor equal in value a day of various classes of skilled labors of the locksmith, of the watchmaker, of the inventor of the physician, etc.); and so long as this table of labor is not made, collectivism is not applicable, for it is according to this list that social labor is valued and paid, and so long as the socialist leaders do not apply themselves to the preparation of such a table they show that they do not believe in he advent of collectivism. 
Beside this rude socialism of the masses, there is that of the middle class, that of the upper classes ; and this aristocratic socialism, this "good" socialism, is simply a modern garment given to venerable charity, or again, that utopian aureole which succeeds to the religious aureole which has always surrounded benevolence, humanity, love of one's neighbor. These utopian sentiments exercise to-day a great influence over men of the most diverse tendencies. Such sentiments are at least disinterested, or have that appearance. So, then, there is much economic practice without much attention to theory, and if theory looks as if it would grumble, the label is changed, and instead of "economic" "social"* is used; and if one has a tender heart, he deludes himself, and is persuaded that it is good. Even economists, well founded in their principles, allow themselves, if not to do as the Romans do, at least to make concessions. They can do this without a blush, for practice always leaves a certain-sometimes a great-latitude to individual taste: one can waive a portion of his rights. Upon the limit to place in this matter, nothing is yet decided. Opinions are fermenting ; and we must wait until they are clarified. Only the masses-or rather the demagogues-ask too much : all that they ask cannot be given them. If there be a struggle, if violence occur, then economic laws will show that they may become dormant but do not perish, they punish those who transgress them.

I should have been glad in closing to mention a certain number of contemporary economic publications, to show to what measure the dominant influences had acted upon the authors of to-day who have remained faithful to liberal principles, while making concessions in the matter of practice. It would have been interesting to note these concessions, which may sometimes be involuntary and unconscious of the modifications of doctrine which are the result of reflection or of new experiment, of an "Evolution," as an

\footnotetext{
* The distinction between economic and social is not, perhaps, so apparent in America as in Europe.
} 
extremely modern man would say ;* but such studies of texts exact much space for the writer and much patience for the reader; we will abuse neither the one nor the other. As everywhere, economic study in France is to-day in a state of transition ; let us hope that it will emerge with new strength and brilliancy.

*I have several times attempted to make such comparisons in my work, "Le Progés de la Science économigue" (Paris, Guillaumin).

(Paris).

Maurice Block.

['Translated by Connelia H. B. Rogers] 